\title{
Aqueous Glycosylation of Unprotected Sucrose Employing Glycosyl Fluorides in the Presence of Calcium lon and Trimethylamine
}

\author{
Guillaume Pelletier, Aaron Zwicker, C. Liana Allen, Alanna Schepartz ${ }^{\star}$, and Scott J. Miller \\ Department of Chemistry, Yale University, 225 Prospect Street, New Haven, CT 06520-8107
}

\begin{abstract}
We report a synthetic glycosylation reaction between sucrosyl acceptors and glycosyl fluoride donors to yield the derived trisaccharides. This reaction proceeds at room temperature in an aqueous solvent mixture. Calcium salts and a tertiary amine base promote the reaction with high site-selectivity for either the $3^{\prime}$-position or 1'-position of the fructofuranoside unit. Because nonenzymatic aqueous oligosaccharide syntheses are underdeveloped, mechanistic studies were carried out in order to identify the origin of the selectivity, which we hypothesized was related to the structure of hydroxyl group array in sucrose. The solution conformation of various monodeoxysucrose analogs revealed the cooperative nature of the hydroxyl group in mediating both this aqueous glycosyl bond-forming reaction and the site-selectivity at the same time.
\end{abstract}

\section{Keywords}

aqueous; carbohydrate; glycosylation; glycosyl fluoride; sucrose

\section{Introduction}

The advancement of carbohydrate science depends critically on the ability to synthesize complex sugars in a highly selective manner. Tremendous successes have been achieved in carbohydrate synthesis, both in terms of efficiency and complexity in many synthetic settings. ${ }^{1}$ Specifically, a large number of methods for the construction of the challenging glycosidic linkage has emerged. Most laboratory syntheses rely on the use of activating groups to enable glycosidic bond formation via bimolecular substitution $\left(\mathrm{S}_{\mathrm{N}} 2\right)$ or via an activated oxocarbenium intermediate $\left(S_{N} 1\right){ }^{2}$ The electrophilicity of these intermediates necessitates a protecting group strategy for successful coupling, avoiding reaction with other undesired hydroxyl groups. ${ }^{3}$ It also precludes the use of aqueous solvent. Thus, protecting group-free synthetic glycosylation reactions under aqueous conditions towards oligosaccharides are scarce. ${ }^{4}$ Enzymatic methods using glycosyl transferases or

*Corresponding Author: scott.miller@yale.edu, alanna.schepartz@yale.edu.

Supporting Information. Additional figures, experimental details and characterization. This material is available free of charge via the Internet at http://pubs.acs.org.

Author Contributions: The manuscript was written through contributions of all authors. All authors have given approval to the final version of the manuscript. 
hydrolases, ${ }^{5,6,7}$ however, afford efficient and selective reactions in buffered water, employing pre-fashioned sugar nucleotides or non-reducing sugar as the glycosyl donors (Figure 1). ${ }^{8}$ The enzymatic catalysts harness considerable molecular complexity to achieve the necessary precision in the active site such that the transition state favors glycosylation between a glycosyl donor and acceptor, while hydrolysis does not conspire to prevent the coupling.

With the long-term objective of developing efficient and selective glycosylation reactions independent of enzyme specificities, we aimed to discover the requirements for nonenzymatic glycosylation reactions conducted in water and with no protecting group used at any stage. ${ }^{9}$ Initially, we sought to search for simple glycosyl donors that would be potentially reactive at the $\mathrm{C} 1$-position, while exhibiting stability in water. In this context, we selected glycosyl fluorides as the donor, ${ }^{10}$ which have been extensively studied by Jencks as models of substrates involved in the hydrolysis of glycosidic bonds (Scheme 1a). ${ }^{11}$ More precisely, Jencks showed that a-D-glucosyl fluoride (1a) reacts in an aqueous solution of sodium azide and acetate salts to produce the corresponding $\beta$-anomers $\mathbf{2 a - b}$, overcoming the formation of $\mathrm{p}_{\mathrm{g}}$ glucose. However, the aqueous solvolysis of glycosyl fluorides in the presence of different alcohols as potential nucleophiles revealed a preference for reaction with water. No glycosylations of weakly nucleophilic alcohol acceptors were observed. These results theoretically preclude glycosylation with typical polyol acceptors in the absence of an activator (or catalyst).

Subsequent experimentation disclosed that these reactions were found to be concerted only in presence of strong nucleophiles. These postulates were later revisited by Chan and Bennet, who observed 1a to react with weakly nucleophilic alcohols, such as 1,1,1trifluoroethanol (TFE) or hexafluoro-1-propanol (HFPN), under anhydrous conditions. ${ }^{12}$ Substitution occurs via an $\mathrm{S}_{\mathrm{N}}$-like pathway, wherein the fluoride and an oxocarbenium-like species are present in the transition-state as an intimate, non-solvated ion-pair (Scheme 1b). ${ }^{12,13}$ The capability of the leaving fluoride ion to engage in hydrogen bonding allows for a general acid/base catalysis mechanism to ensue. ${ }^{12 a, 14}$ The conclusions of these reports, as well as the widespread applications of glycosyl fluorides as "transition state analogue substrates" (TSAS) for hydrolase enzymes grounded our interest in these monomers as potential substrates for aqueous glycosylation. ${ }^{15}$

Inspired by the divalent metal cation-dependent nature of many glycosyltransferases, ${ }^{16}$ we postulated that a combined Lewis acid/Lewis base approach might provide the necessary transition state organization to favor glycosylation of the glycosyl fluoride while outcompeting hydrolysis (Figure 2). This strategy could also enhance the reactivity of any alcohol towards substitution. A close comparison can be made with traditional synthetic strategies that rely on an alcohol chelation when metals are employed as catalysts for hydroxyl group functionalization in organic solvents. ${ }^{1 \mathrm{c}}$ As part of this analysis, we were aware of the affinity of various sugars for certain water-soluble main group metal salts, including $\mathrm{Ca}^{2+}, \mathrm{Na}^{+}, \mathrm{K}^{+}$and $\mathrm{Mg}^{2+}$, and this could be exploited to achieve complexationinduced glycosylation. ${ }^{17,18}$ 
Toward the development of such a reaction, we chose to examine sucrose as the glycosyl acceptor due to its high solubility in water, intrinsic natural abundance and low cost. Furthermore, as a polyol, this substrate offers ample opportunity to explore site-selectivity in parallel with the development of a glycosylation reaction. ${ }^{19,20}$ We describe herein the successful elaboration of non-enzymatic, chemoselective glycosylation reactions between glycosyl fluorides and sucrosyl acceptors. The unique nature of the transformations is elucidated through independent synthesis and evaluation of eight unique deoxysucrose substrates. These experiments culminate in the delineation of the specific hydroxyl group array that is required for successful aqueous glycosyl transfer. These findings may offer a framework for the generalization of this approach beyond sucrose, providing a possible bridge between non-enzymatic glycosylation and the aqueous environments endemic to enzymatic catalysis.

\section{Results and Discussion}

\section{Discovery of an Aqueous Glycosylation of Sucrose}

Following Jencks' and our own investigations into reactions of minimally protected carbohydrates, ${ }^{11,21}$ we studied the reactivity of $\mathrm{a}^{-\mathrm{D}}$-glucosyl fluoride 1a towards an aqueous solution of sucrose, a complex carbohydrate acceptor (Scheme 2). ${ }^{22}$ When treated with 0.5 equivalent of sucrose in the absence of any additives, compound 1a hydrolyzes slowly and cleanly to generate $\mathbf{a}$ - and $\beta$-D-glucopyranose (3a and $\mathbf{3 b}$ respectively) in $9 \%$ yield after 48 hours at room temperature. In a separate control experiment, 1.0 equiv. of $\mathrm{Ca}\left(\mathrm{NO}_{3}\right)_{2} \cdot 4 \mathrm{H}_{2} \mathrm{O}$ was found to accelerate hydrolysis of $\mathbf{1 a}$, while no glycosylation was observed. This behavior was found to be general, as the replacement of $\mathrm{Ca}^{2+}$ with other main group salts $\left(\mathrm{Li}^{+}, \mathrm{K}^{+}, \mathrm{Na}^{+}, \mathrm{Mg}^{2+}, \mathrm{Ba}^{2+}, \mathrm{Cs}^{+}\right)$or water soluble transition metals $\left(\mathrm{Cu}^{2+}, \mathrm{Ni}^{2+}, \mathrm{La}^{3+}, \mathrm{Zr}^{4+}\right)$ led to no reaction or to a comparable rate of hydrolysis for the fluoride 1a. The addition of an aqueous base $\left(\mathrm{NMe}_{3}\right)$ alone also furnished the hydrolysis products $\mathbf{3} \mathbf{a} / \mathbf{3 b}$, along with the cyclization product 1,6 -anhydro- $\beta$-glucose $4 .{ }^{12 a}$ Strong bases $(\mathrm{NaOH}$ or $\mathrm{NaOMe}$, for example) were found to give extensive amounts of compound $\mathbf{4}$ and degradation byproducts. On the other hand, addition of both $\mathrm{Ca}\left(\mathrm{NO}_{3}\right)_{2} \cdot 4 \mathrm{H}_{2} \mathrm{O}$ and trimethylamine afforded the glycosylation product $7 \mathbf{a}$ in $20 \%$ yield (with respect to sucrose) after 48 hours. A close examination of both the unpurified and purified reaction mixtures by ${ }^{1} \mathrm{H} N \mathrm{NR}$ in $\mathrm{D}_{2} \mathrm{O}$ revealed that the reaction proceeded with both complete stereochemical inversion of the anomeric center of the glycosyl donor and with complete regioselectivity for the $3^{\prime}$ position of the fructofuranoside unit of sucrose. ${ }^{22}$ This was confirmed by a HMBC NMR analysis of 7a between the carbon at position $\mathrm{C}-3^{\prime}$ of the fructofuranose unit and the axial proton $\mathrm{H}-\mathrm{1}^{\prime \prime}$, geminal to the newly formed $O-\beta$-Glc anomeric linkage (highlighted in cyan, Scheme 2). ${ }^{22}$

In addition to the previously detected side-reactions (towards $\mathbf{3 a}, \mathbf{3 b}, \mathbf{4}$ ), we observed the formation of a small quantity of $\mathrm{D}$-fructose (Fru) (6). Interestingly, hydrolysis of a-D-glucosyl fluoride donor 1a to $\mathrm{D}$-glucose appears to rearrange to form ${ }_{\mathrm{D}}$-fructose $(\mathbf{6})$ under the reaction conditions (with $\mathrm{CaCl}_{2}$ instead of $\left.\mathrm{Ca}\left(\mathrm{NO}_{3}\right)_{2} \cdot 4 \mathrm{H}_{2} \mathrm{O}\right) \cdot{ }^{23}$

This precedented glucose/fructose rearrangement is also known to occur with simultaneous epimerization of D-glucose (Glc) (3a/3b) to o-mannose, which we also observed. Thus, we suspect that $\mathbf{6}$ is formed from an isomerization process and not from the decomposition of 
sucrose and/or 7a. Indeed, extensive decomposition of sucrose or 7a does not occur when they are treated with $\mathrm{Ca}^{2+}$ and aqueous $\mathrm{NMe}_{3}$ in the absence of $\mathbf{1 a}$. In addition, we were able to identify and characterize the $\beta$-trimethylammonium glucosyl fluoride $\mathbf{5}$, generated from stereoinvertive nucleophilic addition of $\mathrm{NMe}_{3}$ to $1 \mathrm{a}$. Through control experiments, we also found that product $\mathbf{5}$ is formed when $\mathbf{1 a}$ is subjected to the reaction conditions in the absence of the glycosyl donor. ${ }^{22,24}$ The formation of any epoxide intermediate formed from 1a was not observed. ${ }^{25}$

\section{Optimization of Conditions}

With the striking observation that 7a can be formed under aqueous conditions, we decided to optimize the glycosylation reactions conditions to give this isomer in high yields (Table 1).

Initially, we found that an excess of 1a (5 equivalents) and a high concentration of $\mathrm{Ca}\left(\mathrm{NO}_{3}\right)_{2} \cdot 4 \mathrm{H}_{2} \mathrm{O}$ (8 equivalents) led to an improved efficiency such that $42 \%$ conversion to 7a could be obtained as a single stereo- and regioisomer (entry 1, with respect to sucrose as the limiting reagent). A screen of various additives revealed that only $\mathrm{Ca}^{2+}$ salts are effective at promoting glycosylation over hydrolysis of $\mathbf{1 a}$ (e.g. no reaction was observed with $\mathrm{NaNO}_{3}$ and $\mathrm{KNO}_{3}$, entries 2-3). A strong effect of the counterion was observed, with dissociated anions $\left(\mathrm{CaBr}_{2} \cdot \mathrm{xH}_{2} \mathrm{O}\right.$ and $\mathrm{Ca}(\mathrm{OTf})_{2}$, more soluble salts) affording reactivity, whereas no reactivity was observed with insoluble or partially soluble salts containing more basic counterions $\left(\mathrm{CaCO}_{3}\right.$ or $\mathrm{CaSO}_{4} \cdot 2 \mathrm{H}_{2} \mathrm{O}$, entries $\left.4-7\right)$. With salts possessing highly dissociable counterions (e.g., triflate, nitrate, iodide), we observed a marked dependence of the conversion to $\mathbf{7 a}$ on the concentration of sucrose in the aqueous medium.

At a higher concentration of sucrose $(>1.0 \mathrm{M})$ and with 8 equivalents of $\mathrm{Ca}(\mathrm{OTf})_{2}$, no reactivity is observed; however, with a more dilute solution $(0.5 \mathrm{M})$ in sucrose, an improved $69 \%$ conversion to $7 \mathbf{a}$ is obtained (c.f., entries 7,8 and 10). Interestingly, this important jump in reactivity is also observed with $\mathrm{Ca}\left(\mathrm{NO}_{3}\right)_{2} \cdot 4 \mathrm{H}_{2} \mathrm{O}$, but to a lesser extent $(42 \%$ at $1.0 \mathrm{M}$ to $50 \%$ at $0.5 \mathrm{M}$, entries 1 and 9 ). When the reaction is conducted in the presence of 7.0 equivalents of both $\mathrm{Ca}(\mathrm{OTf})_{2}$ and $\mathbf{1 a}$, we found that a concentration of $0.30 \mathrm{M}$ in sucrose was optimal (entry 13). ${ }^{26}$ The equivalents of calcium salt and fluoride donor could be adjusted to 6.0 equivalents without a concomitant decrease in reactivity ( $82 \%$, entry 15$)$, but further decreasing the equivalents impeded the reaction rate and lower yields of $7 \mathbf{a}$ were observed. ${ }^{22}$ Modifying the base and/or ratio of base relative to water was detrimental since hydrolysis of 1a was found to be more extensive (69\% with $30 \%$ aq. $\mathrm{NMe}_{3}$, entry 16). We were able to achieve glycosylation on a practical scale by elevating the temperature to $30{ }^{\circ} \mathrm{C}$, which afforded the desired product in $80 \%$ isolated yield (1.0 mmol of sucrose, entry 17). The product 7a can be readily purified by column chromatography. Assessment of its purity by conventional NMR and combustion analysis demonstrated that the monosaccharides byproducts, silica gel or residual calcium salts are indeed removed by this method.

Alternatively, peracetylation of the trisaccharide $7 \mathbf{a}\left(\mathrm{Ac}_{2} \mathrm{O} / \mathrm{DMAP} \text { in pyridine }\right)^{22}$ provided a derivative that is soluble in conventional organic solvents.

\section{Reaction Scope}

Encouraged by these results with sucrose, we decided to investigate the glycosylation of other sucrose-like oligosaccharides (Scheme 3). We were eager to see if the high selectivity 
observed for product 7a could be translated to more complex polyols. For example, xylosucrose, raffinose pentahydate, and stachyose hydrate, oligosaccharides of biosynthetic origin and readily obtained from commercial suppliers, afforded the desired glycosylated products $\mathbf{7 b}, \mathbf{7 c}$, and $\mathbf{7 d}$ in practical yields (in 76\%, 59\%, 55\% yields respectively). With stachyose, the product and starting saccharide were found to co-elute, and peracylation (with $\mathrm{Ac}_{2} \mathrm{O} / \mathrm{DMAP}$ in pyridine) of the mixture was necessary in order to isolate the pure product.

Strikingly, under the optimized $\mathrm{Ca}(\mathrm{OTf})_{2}$ conditions, we obtained exclusively the $3^{\prime}$ glycosylated products with no significant quantities of products derived from alternate sites of glycosylation (by ${ }^{1} \mathrm{H}$ NMR analysis of the unpurified reaction mixture). This is perhaps most impressive for stachyose (7d), which possesses 14 distinct hydroxyl groups as candidate acceptor sites, each in a different chemical environment. Moreover, the reaction conditions could be transposed accordingly to lactosyl fructofuranoside $(88 \%, 7 \mathbf{e})$ and erlose $(91 \%, 7 \mathbf{g})$, two other saccharides possessing a $O-\beta-G a l$ and $O-a-G l c$ linkage, respectively, at the 4-position of the Glc unit of the sucrose backbone. a-Fluoro-d-glucose (1a) could also be effectively replaced with a-fluoro-D-maltose (1b) in the presence the of lactosyl fructofuranoside, providing the pentamer $\mathbf{7 f}$ in $47 \%$ yield (the remainder of the mass consisting of starting material). Synthetic sucrose substrates were also found to be compatible with the reaction conditions $(74 \%, \mathbf{7 h} ; 69 \%, \mathbf{7 i} ; 80 \%, \mathbf{7 j}) .7 \mathbf{j}$ is also a potential precursor to aminoglycoside scaffolds, a renowned family of antibiotics ${ }^{27}$ and inhibitors of the dextransucrase enzymes of microorganisms responsible for dental caries. ${ }^{28}$ However, sucralose, an approved no-calorie sweetener, ${ }^{29}$ could not be converted into the corresponding trisaccharide $\mathbf{7 k}$.

\section{Mechanism-Driven Studies}

The differences between sucrose and sucralose are subtle; chlorine atoms replace the hydroxyl groups at positions 4 (Glc), 1' (Fru), and 6' (Fru). The chlorine at position 4 (Glc) of sucralose is also in the inverted axial configuration in contrast to the sucrose equatorial hydroxyl group.

In search of an explanation for this striking regioselectivity exhibited by sucrose-like compounds, and the absence of reactivity for sucralose, we encountered reports by Davies comparing the intramolecular hydrogen bonding networks within various sucrose derivatives ${ }^{30}$ A conclusion from these studies is that sucrose possesses two prominent and competing conformations (A and $\mathbf{B}$ ) in DMSO- $d_{6}$ (eq. 1). These conformations arise from a strong intramolecular hydrogen bond between the 1'-hydroxyl (Fru) and 2-hydroxyl (Glc), and between the 3'-hydroxyl (Fru) and 2-hydroxyl (Glc). However, the substitution of OH-1' with a $\mathrm{Cl}$ atom precludes the latter interaction, and only the first hydrogen bond is present in sucralose. 


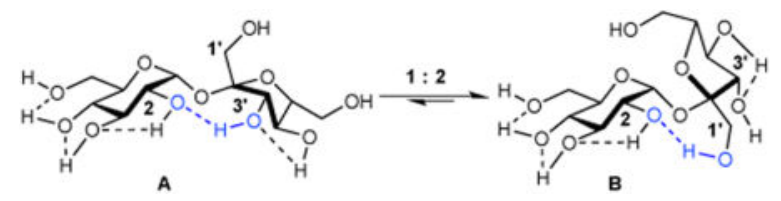

These differences in the hydrogen-bonding network of sucrose and sucralose as well as the observed impact of the various hydroxyl groups on the effectiveness of glycosylation led us to interrogate each of them individually. In order to do so, we performed a complete deoxygenation scan by single hydroxyl group deletion present in sucrose. We synthesized each of the deoxysucroses $(\mathbf{8 a - 8 h})$ following either reported literature procedures or conventional orthogonal protecting group strategies (See Supporting Information for extensive details). ${ }^{22,31}$ We then submitted them to the optimized $3^{\prime}$-glycosylation conditions (c. f. conditions of Scheme 3).

Remarkable and nearly binary results were observed with all permutations (Table 2). 2Deoxysucrose (8d), 1'-deoxysucrose (8e), and $3^{\prime}$-deoxysucrose $(\mathbf{8 f})$ are completely inactive under the reaction conditions. On the contrary, 6-deoxysucrose $(\mathbf{8 a})$, 4-deoxysucrose $(\mathbf{8 b})$, and 6 '-deoxysucrose $(\mathbf{8 h})$ all give nearly full conversions and yields for the $3^{\prime}$-glycosylated trimers $(90 \%, 82 \%$, and $93 \%$ yields respectively for $\mathbf{9 a}, \mathbf{9 b}$, and $\mathbf{9 h}$ ).

3-Deoxysucrose (8c) and 4'-deoxysucrose (8g) exhibit intermediate activity, the former giving very low conversion $(<5 \%)$.

\section{Data Analysis}

An understanding of the conformation of sucrose and its deoxygenated derivatives would offer insight into the remarkable regioselectivity observed in this glycosylation reaction. Toward this end, we studied the solution structures of all species (c.f., eq 1), looking for differences that correspond to a specific hydroxyl group deletion. ${ }^{30}$ For example, we suspected that elimination of the 2-Glc hydroxyl might have a profound effect on the sucrose conformation in solution ( $\mathrm{OH}$ replaced for $\mathrm{H}$, in red, eq. 2)

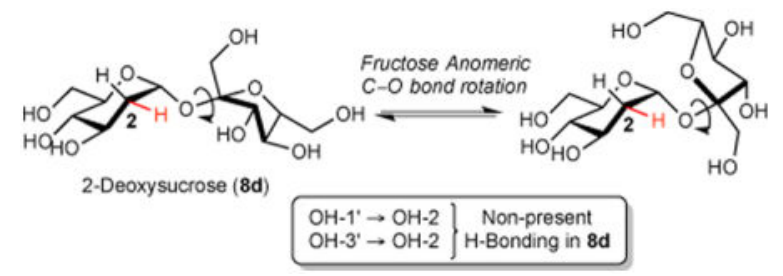

Davies and O'Leary used equilibrium isotope effects to elucidate intramolecular hydrogen bonding arrays in polyol substrates. ${ }^{30,32}$ Thus, we elected to examine qualitative correlations 
among sucrose, sucralose, and deoxysucroses 8a-8h (Table 3). The nature of these solution conformations was probed using the SIMPLE ${ }^{1} \mathrm{H}$ NMR technique ( Secondary Isotopic Multiplets of Partially Labelled Entities; SIMPLE) in DMSO- $d_{6}$, in which intermolecular Hto-D exchange between substrates (or with solvent) is slow. ${ }^{30}$ The SIMPLE phenomenon observed by Davies for sucrose at $\mathrm{OH}-2, \mathrm{OH}-1^{\prime}$, and $\mathrm{OH}-3^{\prime}$ is amplified at these sites (highlighted in blue, eq. 1), and is explained by invoking several cooperative hydrogen bonds between the other $\mathrm{OH}$-groups that are present. Consequently, when these interactions are absent, as in the case of OH-to-Cl substitutions in sucralose, the SIMPLE effects are attenuated. ${ }^{29}$

For the purpose of our study, we compared the equilibrium isotopic perturbations associated with the predominant $\mathrm{OH}-1^{\prime} \rightarrow \mathrm{OH}-2$ and $\mathrm{OH}-3^{\prime} \rightarrow \mathrm{OH}-2$ H-bonds initially reported for sucrose and sucralose in DMSO- $d_{6}$ by Davies (Table 3). ${ }^{30}$ Deoxysucrose derivatives that undergo highly efficient $3^{\prime}$-glycosylation $(\mathbf{8 a}, \mathbf{8 b}, \mathbf{8 g}$ and $\mathbf{8 h}$; c.f., Table 2, entries 1, 2, 7 and 8) reveal SIMPLE ${ }^{1} \mathrm{H}$ NMR data that is homologous with sucrose itself. More precisely, slightly more downfield isotopic shifts for $\mathrm{OH}-2\left(+85\right.$ and $\left.+79 \times 10^{-4} \mathrm{ppm}\right)$ associated with the $\mathrm{OH}-1^{\prime} \rightarrow \mathrm{OH}-2$ intramolecular hydrogen bonds are observed with deoxysucrose $\mathbf{8 a}$ and $\mathbf{8 b}$, in comparison to sucrose $\left(+70 \times 10^{-4} \mathrm{ppm}\right)$. Notably, these substrates provide somewhat faster reactions than sucrose under identical Ca-mediated glycosylation conditions. Yet the magnitude of the corresponding isotopic shift decreases for substrate $8 \mathbf{c}\left(+56 \times 10^{-4} \mathrm{ppm}\right)$ and it is absent altogether for 2-deoxysucrose $\mathbf{8 d}$. This may reflect a weaker hydrogen bond in the case of $\mathbf{8 c}$, and the absence of critical hydrogen-bonding for $\mathbf{8 d}$. Accordingly, the glycosylation for those substrates was found to be greatly inhibited (c.f., Table 2, entries 3 and 4). Notably, other poor substrates for the glycosylation reactions also reflect significantly altered intramolecular hydrogen-bonding arrays in comparison to sucrose.

For example, $8 \mathbf{e}$ and $\mathbf{8 f}$ exhibit isotopic shifts at $\mathrm{OH}-2$ roughly two times higher than those observed for sucrose $\left(+128\right.$ and $+130 \times 10^{-4} \mathrm{ppm}$ vs $\left.+70 \times 10^{-4} \mathrm{ppm}\right)$. Moreover, only one hydrogen bond induces a SIMPLE effect for $\mathbf{8 e}$ and $\mathbf{8 f}$. This pattern is also observed for sucralose; the single $\mathrm{OH}-3^{\prime} \rightarrow \mathrm{OH}-2$ network exhibits a lower but significant $+30 \times 10^{-4}$ ppm isotopic shift with respect to the $\mathrm{OH}-2$ (due to $\mathrm{CI}$ atoms lowering the amount of cooperative hydrogen bonds present). ${ }^{30 \mathrm{a}}$ Thus, it seems likely that the hydrogen-bonding network present in sucrose plays a critical role in determining the reactivity and selectivity this glycosylation method. Deletion of the hydroxyl group at positions 2-Glc, 1'-Fru and 3'Fru not only alters the hydrogen-bonding network, but has a profound effect on the overall nucleophilicity of the sugar and its corresponding interactions with $\mathrm{Ca}^{2+}$ under the reaction conditions. All of these effects could influence the substrates' $\mathrm{p} K_{\mathrm{a}}$ values as well. Sucrose has an estimated $\mathrm{p} K_{\mathrm{a}}$ value of 12.6 in water and the most acidic position was calculated by Houdier and Pérez to be at the 2-hydroxyl (Glc). ${ }^{33}$ This unusually high acidity for a polyol (versus a simple alcohol) is thought to be a result of this complex hydrogen-bonding network. ${ }^{20 \mathrm{~b}-\mathrm{d}, 34,35} \mathrm{We}$ suspect that the $\mathrm{p} K_{\mathrm{a}}$ of certain deoxysucrose substrates is altered in comparison to native sucrose as a result of the hydrogen-bonding network perturbation (as observed by SIMPLE NMR). The specifics of the interaction of the sucrosyl hydroxyl group array under our reaction conditions may also prove highly context dependent. For example, studies of sucrose and $C$-sucrose analogs show differing affinity for $\mathrm{Ca}^{2+}$ in methanol 
solvent. ${ }^{36}$ The present aqueous conditions, in the presence of trimethylamine could well alter the equilibrium to favor $\mathrm{Ca}^{2+}$-sucrose adducts of unique reactivity, which seems consistent with our deoxysucrose scan glycosylation results.

\section{Implications for Alternate Regioselectivity}

It is not straightforward to alter the site-selectivity of the present aqueous glycosylation with sucrose as the acceptor. For example, we found that when the reaction is performed with the basic and partially soluble $\mathrm{Ca}(\mathrm{OH})_{2}$, a moderate level of reactivity is still observed (42\% yield), albeit to a much more complicated mixture of trisaccharides products. A close look into product distribution showed that the major product formed is the $\mathrm{l}^{\prime}$-glycosylated regioisomer 10a over the $3^{\prime}$-glycosylated product 7a (in a ratio of roughly 55:45). After reoptimization, ${ }^{22}$ 10a could be obtained in increased yield (65\% yield, 10a:7a ratio of 70:30), and appreciable amounts of this pure trisaccharide could be isolated by prep-HPLC (Scheme 4). ${ }^{37}$ The connectivity and relative stereochemistry of this alternative regioisomer were also supported by HMBC-NMR analysis ${ }^{22}$ between the carbon at position $\mathrm{C}-1^{\prime}$ of the fructofuranose unit and the axial Glc proton $\mathrm{H}-1$ " (highlighted in green, scheme 4).

Contrary to 7a, product 10a was recently isolated by the fermentation of plants extract and comparison of the reported spectroscopic data to ours confirmed its identity. ${ }^{38}$ The regioselectivity for the formation of 10a is consistent with a consideration of the conformational analysis. ${ }^{30}$ As noted earlier, the $1^{\prime}$-hydroxyl group is hydrogen-bonded to the 2-hydroxyl oxygen. The switch of selectivity may be a manifestation of a conformational change when $\mathrm{Ca}(\mathrm{OH})_{2}$ is used. Since sucrose is fairly acidic, its derived calcium alkoxide may substitute the glycosyl fluoride 1a in a conformation different from the one adopted when $\mathrm{Ca}(\mathrm{OTf})_{2}$ is used.

\section{Conclusion}

This glycosylation boasts several unique features: the reaction is carried out under completely aqueous conditions and high levels of glycosylation of sucrose and several of its analogs are observed; the glycosylation proceeds with complete stereoinversion at the anomeric center of the glycosyl donor, as well as complete regioselectivity of the acceptor. From a practical perspective, all of the reagents used are inexpensive, readily available compounds and the procedure itself is experimentally simple. The glycosylation products would be difficult to access using any currently reported glycosylation methods and their synthesis is yet unreported in the literature. More broadly, the mechanistic basis for the unique reactivity foreshadow well for the exploration of substrates beyond sucrose. Could other metal ion/basic additive/carbohydrate combinations be found that allow for the related aqueous glycosylations of other substrates so that the scope could be expanded? This critical question is the focus of ongoing studies in our laboratories.

\section{Supplementary Material}

Refer to Web version on PubMed Central for supplementary material. 


\section{Acknowledgments}

This work was initially supported by the W. M. Keck Foundation and later by National Institutes of Health (NIH GM068649). The authors would like to thank Prof. Daniel J. O'Leary for insightful discussions. G.P. is grateful to NSERC (PDF) and FQRNT (B3) for post-graduate fellowships.

Funding Sources: The authors declare no competing financial interests.

\section{References}

1. (a) Nigudkar SS, Demchenko AV. Chem Sci. 2015; 6:2687-2704. [PubMed: 26078847] (b) Seeberger PH. Acc Chem Res. 2015; 48:1450-1463. [PubMed: 25871824] (c) McKay MJ, Nguyen HM. ACS Catal. 2012; 2:1563-1595. [PubMed: 22924154] (d) Mydock LK, Demchenko AV. Org Biomol Chem. 2010; 8:497-510. [PubMed: 20090962] (e) Zhu X, Schmidt RR. Angew Chem, Int Ed. 2009; 48:1900-1932.(f) Boltje BT, Buskas T, Boons GJ. Nat Chem. 2009; 1:611-622. [PubMed: 20161474] (g) Smoot JT, Demchenko AV. Adv Carbohydr Chem Biochem. 2009; 62:161-250. [PubMed: 19501706] (h) Wang Y, Ye XS, Zhang LH. Org, Biomol Chem. 2007; 5:2189-2200. [PubMed: 17609746] (i) Jung KH, Müller M, Schmidt RR. Chem Rev. 2000; 100:4423-4442. [PubMed: 11749353]

2. (a) Bohé L, Crich D. Carbohydr Res. 2015; 403:48-59. [PubMed: 25108484] (b) Satoh H, Manabe H. Chem Soc Rev. 2013; 42:4297-4309. [PubMed: 23364773]

3.

Stereocontrolled synthetic glycosyl transfers of partially or fully unprotected glycosyl donors have been achieved through several strategies. However, the selectivity challenge is much greater for oligosaccharide synthesis when both glycosyl donor and acceptors are partially or fully unprotected. For reviews, see: Lee D, Taylor M. Synthesis. 2012:3421-3431.Hanessian S, Lou B. Chem Rev. 2000; 100:4443-4463. [PubMed: 11749354] . For recent strategies, see: Goff RD, Thorson JS. Med Chem Commun. 2014; 5:1036-1047.Meng B, Zhu Z, Baker DC. Org Biomol Chem. 2014; 12:5182-5191. [PubMed: 24915049] Williams RJ, Paul CE, Nitz M. Carbohydr Res. 2014; 386:7377. [PubMed: 24491844] Sun X, Lee H, Lee S, Tan KL. Nat Chem. 2013; 5:790-795. [PubMed: 23965682] Gouliaras C, Lee D, Chan L, Taylor MS. J Am Chem Soc. 2011; 133:13926-13929. [PubMed: 21838223] Lee D, Taylor MS. J Am Chem Soc. 2011; 133:3724-3727. [PubMed: 21355584] Mamidyala SK, Finn MG. J Org Chem. 2009; 74:8417-8420. [PubMed: 19827757] Tanaka T, Nagai H, Noguchi M, Kobayashi A, Shoda SI. Chem Commun. 2009:3378-3379.Davis BG, Wood SD, Maughan MAT. Can J Chem. 2002; 80:555-558.

4.

There are a few examples of $O$-, $C$-, and $S$-glycosidic bond-forming reactions performed in water or aqueous biphasic mixtures. These typically include the use of protecting groups and/or multi-step synthesis: Delacroix S, Bonnet JP, Courty M, Postel D, Nguyen van Nhien A. Carbohydr Res. 2013; 381:12-18. [PubMed: 24056009] Sakakura A, Koshikari Y, Akakura M, Ishihara K. Org Lett. 2012; 14:30-33. [PubMed: 22126186] Yoshida N, et al. Chem Asian J. 2011; 6:1876-1885. [PubMed: 21604376] Sato S, Naito Y, Aoki K. Carbohydr Res. 2007; 342:913-918. [PubMed: 17306239] Jensen KJ. J Chem Soc, Perkin Trans. 2002; 1:2219-2233.

5.

Fore reviews, see: Bojarová P, Rosencrantz RR, El-ling L, Křen V. Chem Soc Rev. 2013; 42:47744797. [PubMed: 23348496] Wang LX, Davis BG. Chem Sci. 2013; 4:3381-3394. [PubMed: 23914294] Kadowaka, Ji. Chem Rev. 2011; 111:4308-4345. [PubMed: 21319765] Kobayashi S, Makino A. Chem Rev. 2009; 109:5288-5353. [PubMed: 19824647] Hehre EJ. Carbohydr Res. 2001; 331:347-368. [PubMed: 11398978] Kren V, Thiem J. Chem Soc Rev. 1997; 26:463-

J Am Chem Soc. Author manuscript; available in PMC 2017 March 09. 
473.David S, Augé C, Gautheron C. Adv Carbohydr Chem Biochem. 1991; 49:175-237. [PubMed: 1814172]

6.

For glycosyl transferase examples, see: Singh S, Philipps GN Jr, Thorson JS. Nat Prod Rep. 2012; 29:1201-1237. [PubMed: 22688446] Gantt RW, Peltier-Pain P, Thorson JS. Nat Prod Rep. 2011; 28:1811-1853. [PubMed: 21901218] Blanchard S, Thorson JS. Curr Opin Chem Biol. 2006; 10:263-271. [PubMed: 16675288] Hancock SM, Vaughan MD, Withers SG. Curr Opin Chem Biol. 2006; 10:509-519. [PubMed: 16905354] Williams SJ, Withers SG. Carbohydr Res. 2000; 327:2746. [PubMed: 10968675] van den Eijnden DH. Carbohydrates in Chemistry and Biology. Ernst B, Hart GW, Sinay P. Wiley-VCH Weinheim2000; 1:589-624.Gambert U, Thiem J. Top Curr Chem. 1997; 186:21-43.

7.

For glycosyl hydrolase examples, see: Desmet T, Soetaert W, Bojarová P, Křen V, Dijkhuizen L, Eastwick-Field V, Schiller A. Chem-Eur J. 2012; 18:10786-10801. [PubMed: 22887462] Husain Q. Crit Rev Botechnol. 2010; 30:41-62.Murata T, Usui T. Trends Glycosci Glycotechnol. 2000; 12:161-174.Scigelova M, Singh S, Crout DHG. J Mol Catal B-Enzym. 1999; 6:483-494.

8. (a) Ohrlein, R. Carbohydrates in Chemistry and Biology. Ernst, B.; Hart, GW.; Sinay, P., editors. Vol. 1. Wiley-VCH, Weinheim; 2000. p. 625-646.(b) Nikaido H, Hassid WZ. Adv Carbohydr Chem Biochem. 1971; 26:351-483.(c) Caputto R, Leloir LF, Cardini E, Paladini AC. J Biol Chem. 1950; 184:333-350. [PubMed: 15422002]

9. (a) Young IS, Baran PS. Nat Chem. 2009; 1:193-205. [PubMed: 21378848] (b) Shenvi RA, O'Malley DP, Baran PS. Acc Chem Res. 2009; 42:530-542. [PubMed: 19182997] (c) Hoffmann RW. Synthesis. 2006:3531-3541.

10.

For the activation and application of fully protected glycosyl fluorides, see: Toshima K. Carbohydr Res. 2000; 327:15-27. [PubMed: 10968674] Akçay G, Ramphal JY, d'Alarcao M, Kumar K. Tetrahedron Lett. 2015; 56:109-114. [PubMed: 25530638] Partridge KM, Bader SJ, Buchan ZA, Taylor CE, Montgomery J. Angew Chem, Int Ed. 2013; 52:13647-13650.Shivatar SS, Chang SH, Tsai TI, Ren CT, Chuang HY, Hsu L, Lin CW, Li ST, Wu CY, Wong CH. J Am Chem Soc. 2013; 135:15382-15391. [PubMed: 24032650] Saha J, Peczuh MW. Chem-Eur J. 2011; 17:7357-7365. [PubMed: 21567495] Durham TB, Blanchard N, Savall BM, Powell NA, Roush WR. J Am Chem Soc. 2004; 126:9307-9317. [PubMed: 15281821] Nicolaou KC, Chucholowski A, Dolle RE, Randall JL. J Chem Soc, Chem Commun. 1984:1155-1156.Nicolaou KC, Dolle RE, Papahatjis DP, Randall JL. J Am Chem Soc. 1984; 106:4189-4192.Hashimoto S, Hayashi M, Noyori R. Tetrahedron Lett. 1984; 25:1379-1382.Mukaiyama T, Murai Y, Shoda S. Chem Lett. 1981:431432.

11. (a) Banait NS, Jencks WP. J Am Chem Soc. 1991; 113:7951-7958.(b) Banait NS, Jencks WP. J Am Chem Soc. 1991; 113:7958-7963.

12. (a) Chan J, Tang A, Bennet AJ. J Am Chem Soc. 2012; 134:1212-1220. [PubMed: 22148388] (b) Sinnott ML, Jencks WP. J Am Chem Soc. 1980; 102:2026-2032.

13. Chan J, Sannikova N, Tang A, Bennet AJ. J Am Chem Soc. 2014; 136:12225-12228. [PubMed: 25121958]

14. (a) Stubbs JM, Marx D. J Am Chem Soc. 2003; 125:10960-10962. [PubMed: 12952477] (b) Zhang Y, Bommuswamy J, Sinnot ML. J Am Chem Soc. 1994; 116:7557-7563.

15.

For examples, see: Kittl R, Withers SG. Carbohydr Res. 2010; 345:1272-1279. [PubMed: 20427037]

Kobayashi S. J Polym Sci, Part A: Polym Chem. 2005; 43:693-710.Armand S, Drouillard S, Schülein M, Henrissat B, Driguez H. J Biol Chem. 1997; 272:2709-2713. [PubMed: 9006908]

J Am Chem Soc. Author manuscript; available in PMC 2017 March 09. 
16. (a) Gloster TM. Curr Opin Struct Biol. 2014; 28:131-141. [PubMed: 25240227] (b) Lairson LL, Henrissat B, Davies GJ, Withers SG. Annu Rev Biochem. 2008; 77:521-555. [PubMed: 18518825] (c) Dürr G, Strayle J, Plemper R, Elbs S, Klee SK, Catty P, Wolf DH, Rudolph HK. Mol Biol Cell. 1998; 9:1149-1162. [PubMed: 9571246]

17. (a) Nakagawa Y, Watanabe Y, Igarashi Y, Ito Y, Ojika M. Bioorg Med Chem Lett. 2015; 25:29632966. [PubMed: 26045034] (b) Czugler M, Pintér I. Carbohydr Res. 2011; 346:1610-1616. [PubMed: 21645888] (c) Kato T, Tsubono K, Kamo O, Kato T, Furihata K, Fujimoto T, Machinami T, Tashiro M. Magn Reson Chem. 2009; 47:948-952. [PubMed: 19655368] (d) Zhuo K, Liu H, Zhang X, Liu Y, Wang J. Carbohydr Res. 2008; 343:2428-2432. [PubMed: 18701091] (e) Vega-Cantu YI, Hauge RH, Norman LR, Powell RJ, Billups WE. Biomacromolecules. 2006; 7:441-445. [PubMed: 16471914] (f) Fujimoto T, Oku K, Tashiro M, Machinami T. J Carbohydr Chem. 2006; 25:521-532.(g) Gege C, Geyer A, Schmidt RR. Eur J Org Chem. 2002:2475-2485. (h) Ashton PR, Gattuso G, Königer R, Stoddart JF, Williams DJ. J Org Chem. 1996; 61:95539555 .

18.

The approach illustrated in Figure $2 \mathrm{~b}$ is reminiscent of the metal-directed acetal and stannylene acetal formation on polyol-containing carbohydrates: Iwasaki F, Maki T, Onomura O, Nakashima W, Matsumura Y. J Org Chem. 2000; 65:996-1002. [PubMed: 10814046] Martinelli MJ, Vaidyanathan R, Pawlak JM, Nayyar NK, Dhokte UP, Doecke CW, Zollars LMH, Moher ED, Van Khau V, Kosmrjl B. J Am Chem Soc. 2002; 124:3578-3585. [PubMed: 11929246] Voight EA, Rein C, Burke SD. J Org Chem. 2002; 67:8489-8499. [PubMed: 12444630] Gyurcsik B, Nagy L. Coord Chem Rev. 2000; 203:81-149.Evtushenko EV. Carbohydr Res. 2012; 359:111-119. [PubMed: 22925773] Clarke PA, Kayaleh NE, Smith MA, Baker JR, Bird SJ, Chan C. J Org Chem. 2002; 67:5226-5231. [PubMed: 12126410] Angyal SJ. Aust J Chem. 2000; 53:567570.Angyal SJ. Adv Carbohydr Chem Biochem. 1989; 47:1-43.

19.

Thiem reported a seminal non-selective glycosylation of unprotected sucrose employing glycosyl chlorides, $\mathrm{NaH}$ in DMF. All possible $\mathrm{OH}$ positions of sucrose were glycosylated with no chemoselectivity. See: Steinmann A, Thimm J, Thiem J. Eur J Org Chem. 2007:5506-5513.

20. (a) Daudé D, Remaud-Simeon M, André I. Nat Prod Rep. 2012; 29:945-960. [PubMed: 22763898] (b) Queneau Y, Pinel C, Scherrmann MC. C R Chim. 2011; 14:688-699.(c) Queneau Y, Jarosz S, Lewandowski B, Fitremann J. Adv Carbohydr Chem Biochem. 2008; 61:217-292. [PubMed: 17931552] (d) Queneau Y, Fitremann J, Trombotto S. C R Chim. 2004; 7:177-188.

21. (a) Allen CL, Miller SJ. Org Lett. 2013; 15:6178-6181. [PubMed: 24274325] (b) Han S, Miller SJ. J Am Chem Soc. 2013; 135:12414-12421. [PubMed: 23924210] (c) Pathak TP, Miller SJ. J Am Chem Soc. 2013; 135:8415-8422. [PubMed: 23692563] (d) Lewis CA, Miller SJ. Angew Chem, Int Ed. 2006; 45:5616-5619.(e) Lewis CA, Sculimbrene BR, Xu Y, Miller SJ. Org Lett. 2005; 7:3021-3024. [PubMed: 15987195] (f) Griswold KS, Miller SJ. Tetrahedron. 2003; 59:88698875 .

22.

See Supporting Information for reaction details.

23. (a) Caes BR, Palte MJ, Raines RT. Chem Sci. 2013; 4:196-199. [PubMed: 24596655] (b) Moliner M, Román-Leshkov Y, Davis ME. Proc Natl Acad Sci U S A. 2010; 107:6164-6168. [PubMed: 20308577] (c) Tanase T, Takei T, Hidai M, Yano S. Carbohydr Res. 2001; 333:303-312. [PubMed: 11454337] (d) Bermejo-Deval R, Orazov M, Gounder R, Hwang SJ, Davis ME. ACS Catal. 2014; 4:2288-2299.(e) Angyal SJ. Carbohydr Res. 1997; 300:279-281.(f) Yanagihara R, Soeda K, Shiina S, Osanai S, Yoshikawa S. Bull Chem Soc Jpn. 1993; 66:2268-2272.(g) Tanase T, Murata T, Yano S, Hidai M, Yoshikawa S. Chem Lett. 1987:1409-1412.

24. (a) Iddon L, Bragg RA, Harding JR, Pidathala C, Bacsa J, Kirby AJ, Stachulski AV. Tetrahedron. 2009; 65:6396-6402.(b) Micheel F, Micheel H. Ber Dtsch Chem Ges B. 1932; 65B:258-261.(c) Leehman MR, Thompson CD, Marvel CS. J Am Chem Soc. 1933; 55:1977-1981.

25. Dyfverman A, Lindberg B. Acta Chem Scand. 1950; 4:878-884. 
26.

In runs in which the concentration is higher than $0.5 \mathrm{M}$ in sucrose, the reactants were found to be partially soluble throughout the course of the reaction, thus creating some reproducibility issues at an early stage of the optimization. The reaction can be run in more dilute aqueous solutions $(0.20$ $\mathrm{M}$ or $0.1 \mathrm{M}$ wrt sucrose) without hampering the conversion. A concentration of $0.3 \mathrm{M}$ was found to be more practical and consistent.

27. (a) Hermann T. Cell Mol Life Sci. 2007; 64:1841-1852. [PubMed: 17447006] (b) Magnet S, Blanchard JD. Chem Rev. 2005; 105:477-498. [PubMed: 15700953] (c) Sutcliffe JA. Curr Opin Microbiol. 2005; 8:534-542. [PubMed: 16111914] (d) Vakulenko SB, Mobashery S. Clin Microbiol Rev. 2003; 16:430-450. [PubMed: 12857776]

28. (a) Lee CG, Park JK. Appl Microbiol Biotechnol. 2015; 99:7495-7503. [PubMed: 26016785] (b) Binder TP, Robyt JF. Carbohydr Res. 1985; 140:9-20. [PubMed: 2932220] (c) Thaniyavarn S, Singh S, Maynard CM, Taylor KG, Doyle RJ. Carbohydr Res. 1981; 96:134-137. [PubMed: 6170432]

29. (a) Schiffman SS, Rother KI. J Toxicol Environ Health B Crit Rev. 2013; 16:399-455. [PubMed: 24219506] (b) DuBois GE, Prakash I. Annu Rev Food Sci Technol. 2012; 3:353-380. [PubMed: 22224551] (c) Hough L, Phadnis SP. Nature. 1976; 263:800. [PubMed: 995198]

30.

Christofides JC, Davies DB, Martin JA, Rathbone EB. J Am Chem Soc. 1986; 108:5738-5743. [PubMed: 22175321] Christofides JC, Davies DB. J Chem Soc, Chem Commun. 1985:15331534.Christofides JC, Davies DB. J Am Chem Soc. 1983; 105:5099-5105.. See also Lemieux RU, Bock K. Jpn J Antibiot. 1979; 32:S163-S177. [PubMed: 95123]

31. (a) Barton DHR, McCombie SW. J Chem Soc, Perkin Trans. 1975; 1:1574-1585.(b) Chatgilialoglu C, Ferreri C. Res Chem Intermed. 1993; 19:755-775.

32.

While the magnitude of SIMPLE effects seems well-correlated with intramolecular hydrogen bonding, the absolute sign of the chemical shift perturbation can be highly context dependent and difficult to interpret. See: Vasquez TE Jr, Bergset JM, Fierman MB, Nelson A, Roth J, Khan SI, O'Leary DJ. J Am Chem Soc. 2002; 124:2931-2938. [PubMed: 11902884] Craig BN, Janssen MU, Wickersham BM, Rabb DM, Chang PS, O'Leary DJ. J Org Chem. 1996; 61:9610-9613.Anderson CE, Britt DK, Sangji S, O'Leary DJ, Anderson CD, Rychnovsky SD. Org Lett. 2005; 5:5721-5723. [PubMed: 16321031] O'Leary DJ, Hickstein DD, Hansen BKV, Hansen PE. J Org Chem. 2010; 75:13311342. [PubMed: 19994876] Anderson CE, Pickrell AJ, Sperry SL, Vasquez TE Jr, Custer TG, Fierman MB, Lazar DC, Brown ZW, Iskenderian WS, Hickstein DD, O'Leary DJ. Heterocycles. 2007; 72:469-495.

33. (a) Houdier S, Pérez S. J Carbohydr Res. 1995; 14:1117-1132.(b) Woolley EM, Tomkins J, Hepler LG. J Solution Chem. 1972; 1:341-351.

34. (a) Engelsen SB, Péres S. Carbohydr Res. 1996; 292:21-38.(b) Lichtenthaler FW, Immel S, Pokinskyj P. Liebigs Ann. 1995:1939-1947.(c) Immel S, Lichtenthaler FW. Liebigs Ann. 1995:1925-1938.(d) Hamann CH, Fischer S, Polligkeit H, Wolf P. J Carbohydr Chem. 1993; 12:173-190.

35. Matwiejuk M, Thiem J. Eur J Org Chem. 2012:2180-2187.

36.

O'Leary DJ, Kishi Y. Tetrahedron Lett. 1994; 35:5591-5594.. For different conformational analysis of sucrose in water, see: Poppe L, van Halbeek H. J Am Chem Soc. 1992; 114:1092-1094.Hervé du Penhoat C, Imberty A, Roques N, Michon V, Mentech J, Descotes G, Pérez S. J Am Chem Soc. 1991; 113:3720-3727.McCain DC, Markley JL. J Am Chem Soc. 1986; 108:4259-4264.Adams B, Lerner L. J Am Chem Soc. 1992; 114:4827-4829.

37. 
Both regioisomers (10a and 7a) were found to co-elute by conventional flash chromatography. In order to get pure 10a, a subsequent separation by semi-prep HPLC was needed (XBridge Prep Amide $5 \mu \mathrm{L}$ BEH glycan column using a gradient of $80 \% \mathrm{MeCN}$ in $20 \%$ aq. $\mathrm{NH}_{4} \mathrm{OH} 0.1 \%$ buffer to $50 \%$ $\mathrm{MeCN}$ in $50 \%$ aq. $\mathrm{NH}_{4} \mathrm{OH} 0.1 \%$ buffer).

38. Kawazoe N, Okada H, Fukushi E, Yamamori A, Onodera S, Kawabata J, Shiomi N. Open Glycosci. 2008; 1:25-30.

\section{Abbreviations}

$\begin{array}{ll}\text { Glc } & \text { glucose } \\ \text { Gal } & \text { galactose } \\ \text { Fru } & \text { fructose } \\ \text { aq } & \text { aqueous } \\ \text { HSQC } & \text { Heteronuclear Single Quantum Correlation spectroscopy } \\ \text { HMBC } & \text { Heteronuclear Multiple Bond Correlation } \\ \text { TSAS } & \text { transition state analogue substrate } \\ \text { HFPN } & \text { hexafluoro-1-propanol } \\ \text { TFE } & \text { trifluoroethanol } \\ \text { SIMPLE } & \text { Secondary Isotope Multiplets of Partially Labeled Entities } \\ \text { UDP } & \text { uridine diphosphate } \\ \text { CMP } & \text { cytidine monophosphate } \\ \text { GDP } & \text { guanosine diphosphate }\end{array}$




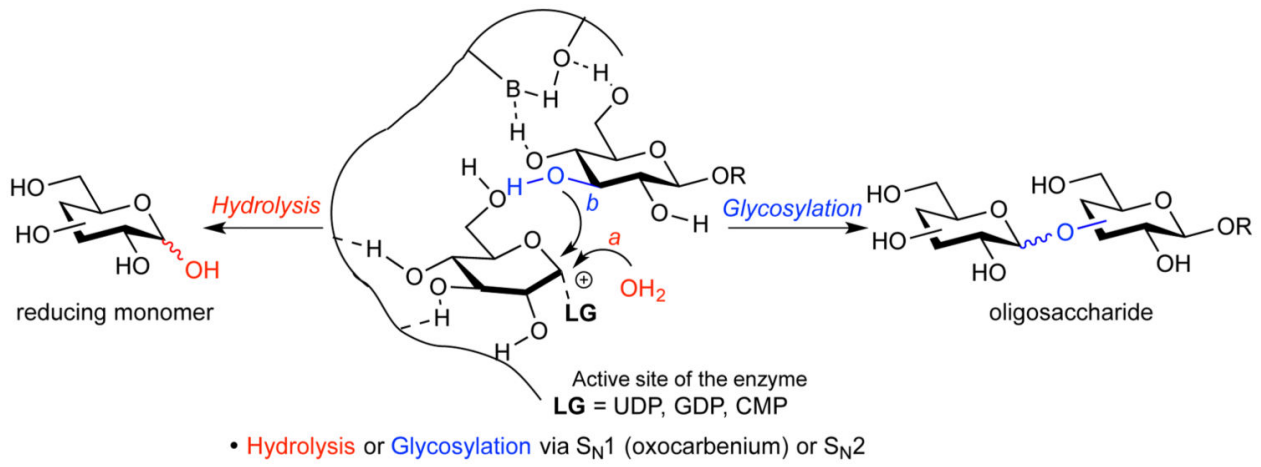

Figure 1.

Competition between hydrolysis $\left(\mathrm{H}_{2} \mathrm{O}\right.$ (a), in red) and glycoside bond formation (acceptor (b), in blue) for a given activated donor in the active site of an enzyme. 
(a) Typical synthetic glycosylation

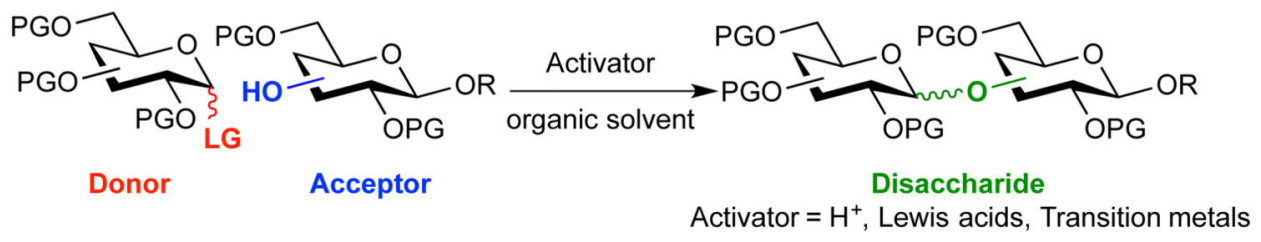

(b) Protecting group-free aqueous glycosylation

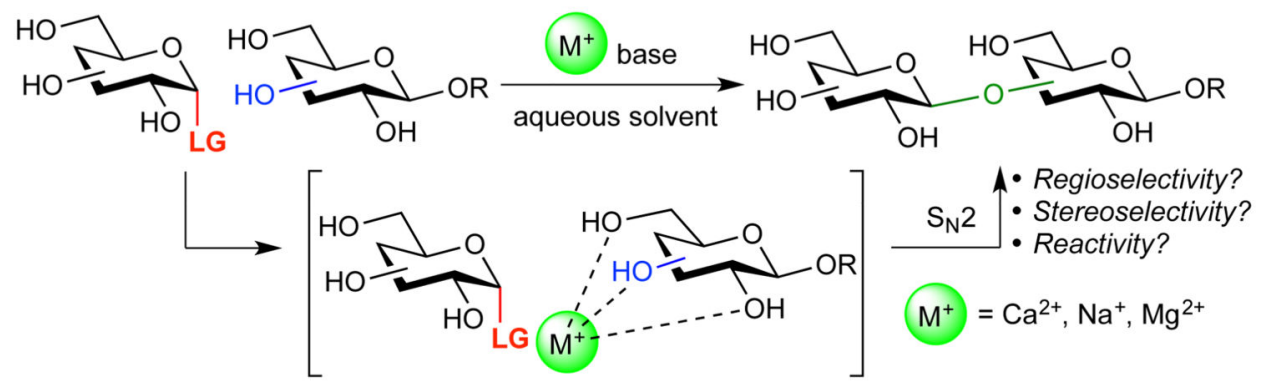

Figure 2.

Synthetic glycosylation strategies for preparation of di- and oligosaccharides: (a) a fully protected donor with a suitable anomeric leaving group reacts with a partially protected acceptor to form a disaccharide in organic solvent; (b) both water soluble donor and acceptor react to form the same bond without the need for directing/protecting groups. 
a)

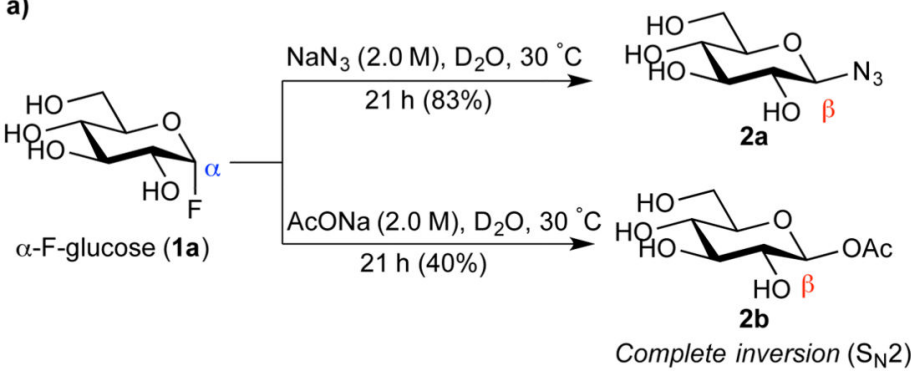

b) Intimate lon-Pair

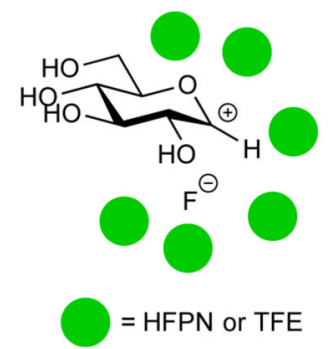

Scheme 1.

Stereoinvertive substitution of a-F-glucose (1a) using simple nucleophiles in water. 


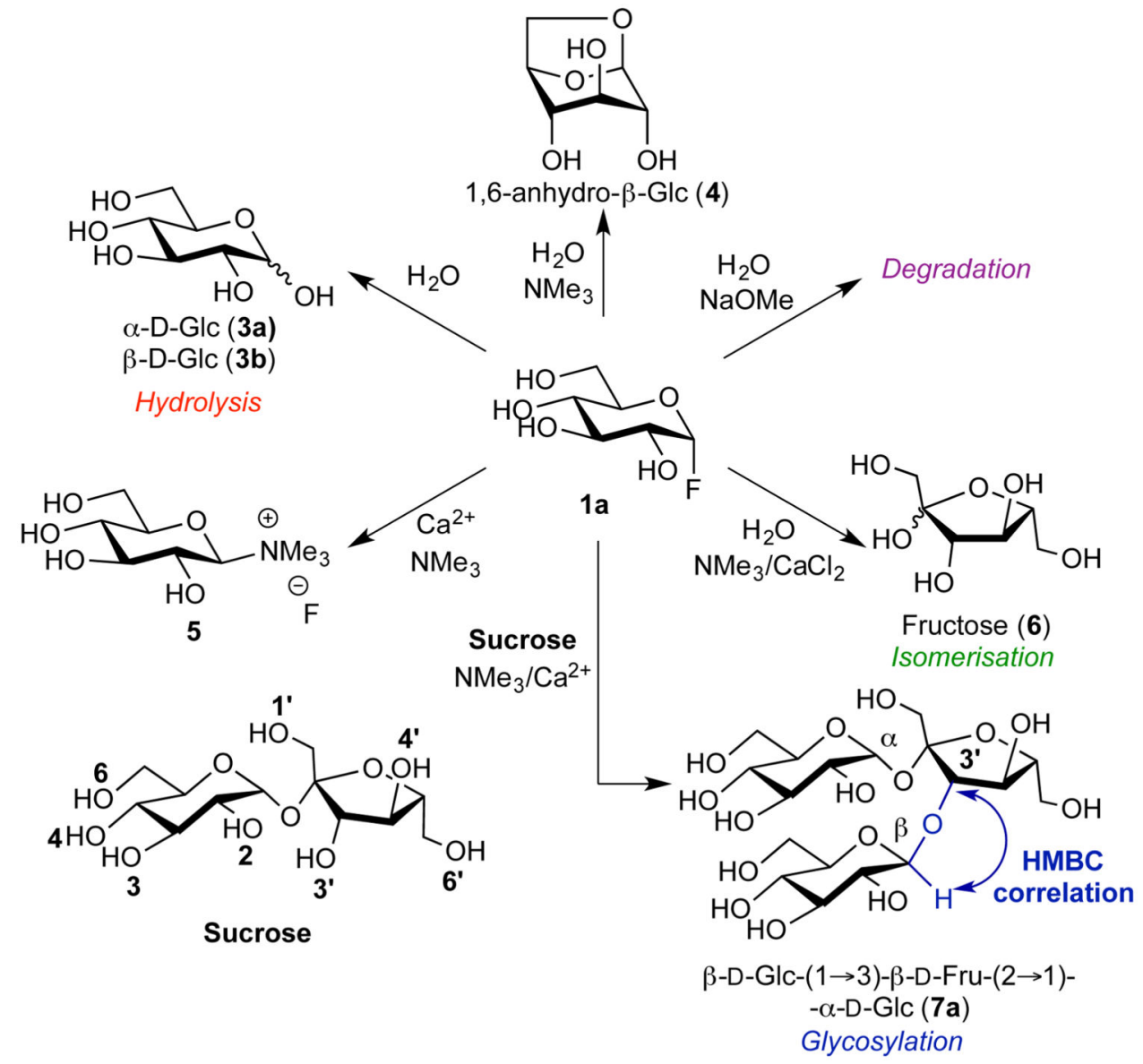

Scheme 2. Observed reaction pathways and formation of a new trisaccharide (7a) 

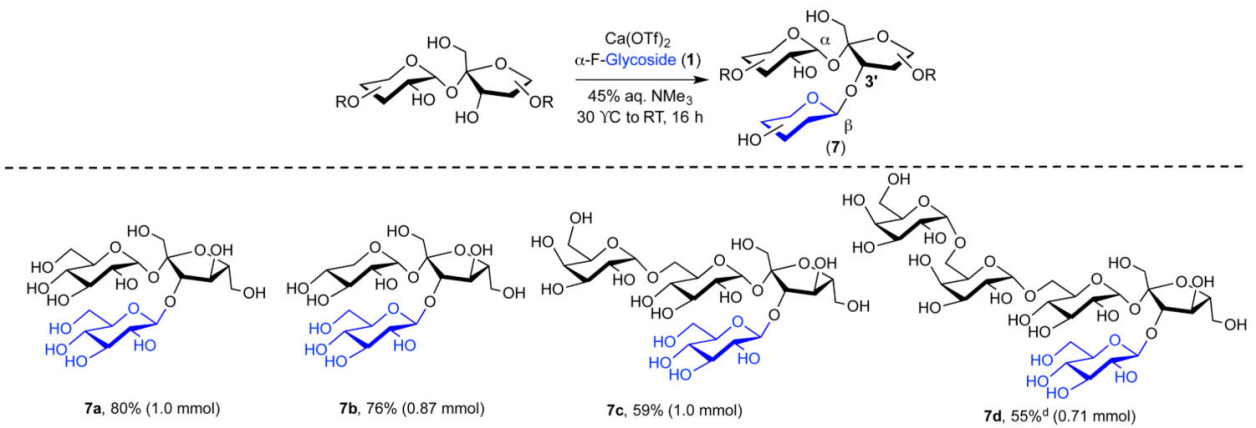

$7 \mathrm{a}, 80 \%(1.0 \mathrm{mmol})$

7b, $76 \%(0.87 \mathrm{mmol})$

$7 \mathrm{c}, 59 \%(1.0 \mathrm{mmol})$

$7 \mathrm{~d}, 55 \% \mathrm{~d}(0.71 \mathrm{mmol})$
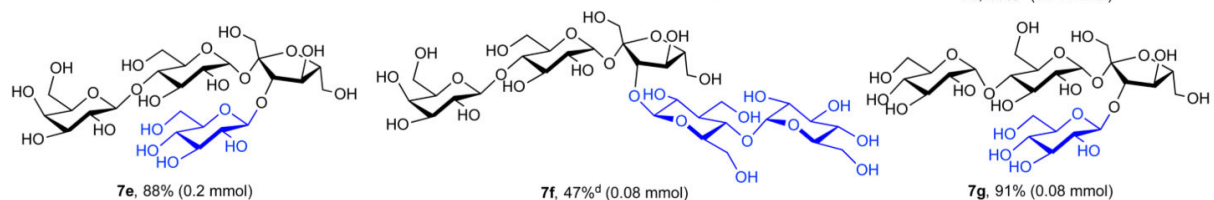

$7 \mathrm{e}, 88 \%(0.2 \mathrm{mmol})$

7f, $47 \%{ }^{\mathrm{d}}(0.08 \mathrm{mmol})$

7g. $91 \%(0.08 \mathrm{mmol})$

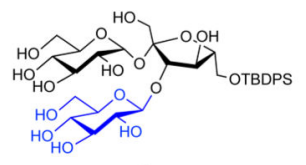

$7 \mathrm{~h}, 74 \%^{\mathrm{d}}(1.0 \mathrm{mmol})$

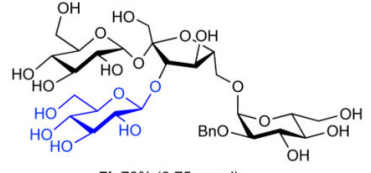

7i, $73 \%$ (0.75 mmol)
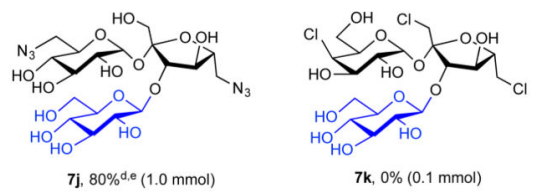

Scheme 3. Scope of the $3^{\prime}$-glycosylation using $\mathrm{Ca}(\mathrm{OTf})_{2}$ optimized conditions $^{\mathrm{a}, \mathrm{b}, \mathrm{c}}$

${ }^{a}$ Reaction conditions: $\mathrm{Ca}(\mathrm{OTf})_{2}$ (6.0 equiv), a-F-Glycoside ( $\mathbf{1 a}$ or $\left.\mathbf{1 b}\right)(6.0$ equiv), $0.30 \mathrm{M}$ in sucrose derivative in $45 \%$ aq. $\mathrm{NMe}_{3}, 30{ }^{\circ} \mathrm{C}, 4 \mathrm{~h}$ then $\mathrm{RT} \mathrm{o} / \mathrm{n}$. ${ }^{\mathrm{b}}$ Isolated yield (\%) after flash

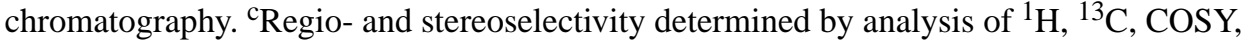
HSQC, and HMBC (see Supporting Information). disolated yield obtained after peracetylation with $\mathrm{Ac}_{2} \mathrm{O}$, DMAP (cat.) in pyridine. ${ }^{e}$ Reaction stirred for 2 hours at $30{ }^{\circ} \mathrm{C}$ only instead of 4 hours at $30^{\circ} \mathrm{C}$ and $\mathrm{RT} \mathrm{o} / \mathrm{n}$. 


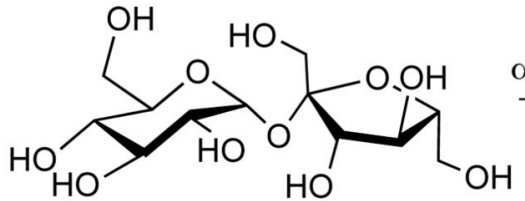

Sucrose

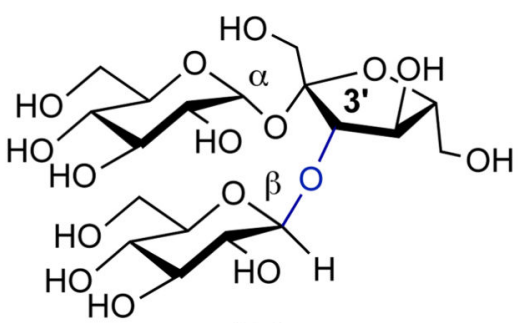

(7a)

$$
\begin{aligned}
& \mathrm{Ca}(\mathrm{OH})_{2} \text { (6.0 equiv) } \\
& \alpha \text {-F-Glucose (1a) (6.0 equiv) } \quad 65 \% \text { yield } \\
& 45 \% \mathrm{NMe}_{3} \text { in } \mathrm{H}_{2} \mathrm{O}(0.1 \mathrm{M}) \quad 10 \mathrm{a} / 7 \text { a ratio : } 70: 30 \\
& \mathrm{NaCl} \text { (10.0 equiv) }
\end{aligned}
$$$$
\mathrm{RT}, 6 \mathrm{~h}
$$

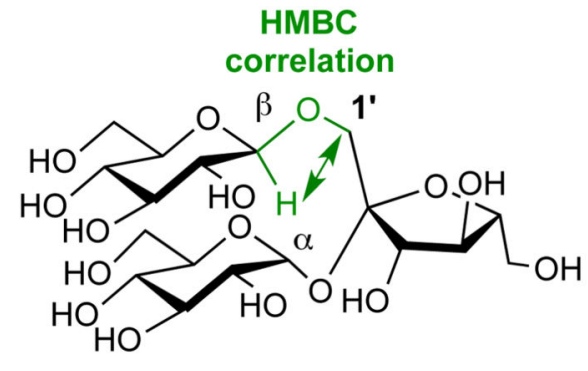

(10a)

Scheme 4. Alternative $\mathrm{Ca}(\mathrm{OH})_{2}$-mediated 1'-glycosylation 
Table 1

Selected optimized parameters for the glycosylation

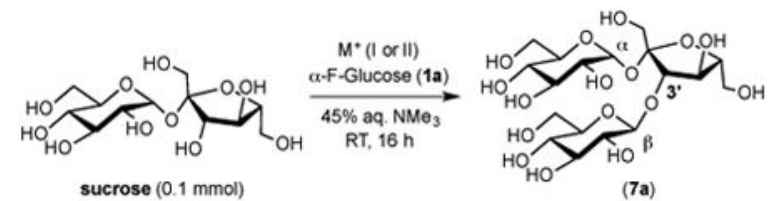

sucrose $(0.1 \mathrm{mmol})$

(7a)

\begin{tabular}{|c|c|c|c|c|}
\hline Entry & $\mathbf{M}^{+}$or $\mathbf{M}^{+}$(equiv) & Conc. $(\mathbf{M})^{a}$ & a-F-Glc (equiv) & Conversion to $7 \mathrm{a}(\%)^{b}$ \\
\hline 1 & $\mathrm{Ca}\left(\mathrm{NO}_{3}\right)_{2}(8)^{\mathcal{c}}$ & 1.0 & 5.0 & 42 \\
\hline 2 & $\mathrm{NaNO}_{3}(8)$ & 1.0 & 5.0 & $<5$ \\
\hline 3 & $\mathrm{KNO}_{3}(8)$ & 1.0 & 5.0 & $<5$ \\
\hline 4 & $\mathrm{CaCO}_{3}(8)$ & 1.0 & 5.0 & $<5$ \\
\hline 5 & $\mathrm{CaSO}_{4}(8)^{\mathcal{c}}$ & 1.0 & 5.0 & $<5$ \\
\hline 6 & $\mathrm{CaBr}_{2}(8)^{\mathcal{C}}$ & 1.0 & 5.0 & 40 \\
\hline 7 & $\mathrm{Ca}(\mathrm{OTf})_{2}(8)$ & 1.0 & 5.0 & 17 \\
\hline 8 & $\mathrm{Ca}(\mathrm{OTf})_{2}(8)$ & 1.5 & 5.0 & $<5$ \\
\hline 9 & $\mathrm{Ca}\left(\mathrm{NO}_{3}\right)_{2}(8)^{\mathcal{c}}$ & 0.50 & 5.0 & 50 \\
\hline 10 & $\mathrm{Ca}(\mathrm{OTf})_{2}(8)$ & 0.50 & 5.0 & 69 \\
\hline 11 & $\mathrm{Ca}(\mathrm{OTf})_{2}(7)$ & 0.50 & 7.0 & 71 \\
\hline 12 & $\mathrm{Ca}(\mathrm{OTf})_{2}(7)$ & 0.40 & 7.0 & 79 \\
\hline 13 & $\mathrm{Ca}(\mathrm{OTf})_{2}(7)$ & 0.30 & 7.0 & 81 \\
\hline 14 & $\mathrm{Ca}(\mathrm{OTf})_{2}(7)$ & 0.20 & 7.0 & 77 \\
\hline 15 & $\mathrm{Ca}(\mathrm{OTf})_{2}(6)$ & 0.30 & 6.0 & 82 \\
\hline 16 & $\mathrm{Ca}(\mathrm{OTf})_{2}(6)$ & 0.30 & 6.0 & $69^{d}$ \\
\hline 17 & $\mathrm{Ca}(\mathrm{OTf})_{2}(6)$ & 0.30 & 6.0 & $87(80)^{e, f, g}$ \\
\hline
\end{tabular}

${ }^{a}$ Concentration of sucrose in the aqueous solvent (M).

${ }^{b}$ Conversion to $7 \mathbf{a}(\%)$ determined by ${ }^{1} \mathrm{H}$ NMR.

${ }^{c}$ Hydrate of the salt was employed

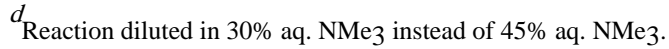

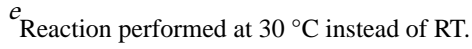

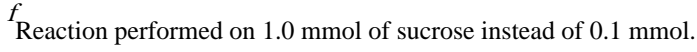

$g_{\text {Isolated yield in parentheses. }}$ 


\section{Table 2}

3'-Glycosylation of Various Deoxysucroses under Optimized Ca(OTf $)_{2}$ Conditions. ${ }^{a, b}$
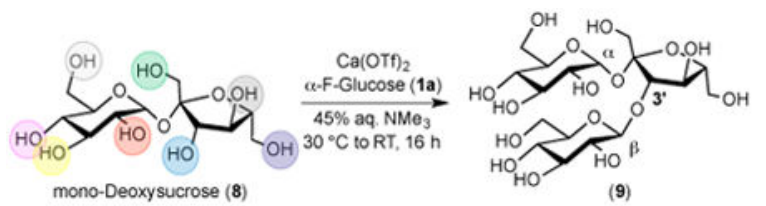

\begin{tabular}{llll}
\hline Entry & Deoxy sucrose derivative (8) & Conversion $(\%)^{c}$ & Yield 9(\%)d \\
\hline
\end{tabular}

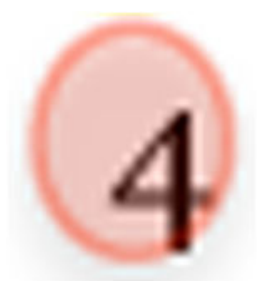




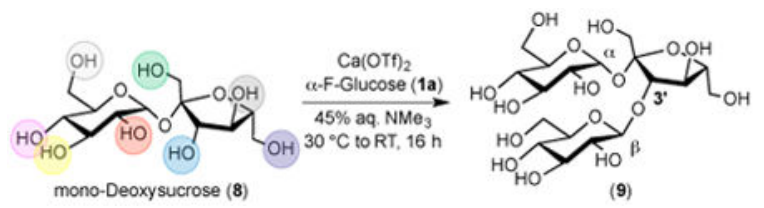

\begin{tabular}{llll}
\hline Entry & Deoxy sucrose derivative (8) & Conversion $(\%)^{c}$ & Yield 9(\%) \\
\hline
\end{tabular}

1'-Deoxysucrose (8e)

3'-Deoxysucrose (8f)

4'-Deoxysucrose (8g)

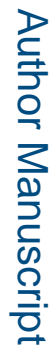
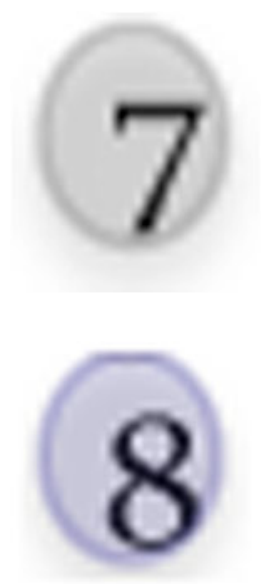

6'-Deoxysucrose $(\mathbf{8 h})$
0

0

65

100

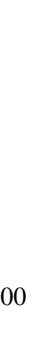

0

0

60

93

Each color denotates a position where an hydroxyl group was selectively removed.

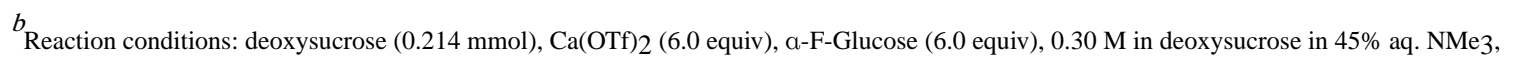
$30^{\circ} \mathrm{C}, 4 \mathrm{~h}$ then $\mathrm{rt}, \mathrm{o} / \mathrm{n}$.

${ }^{c}$ Conversion (\%) determined by ${ }^{1}$ H NMR.

${ }^{d}$ Yield (\%) isolated by flash chromatography.

J Am Chem Soc. Author manuscript; available in PMC 2017 March 09. 


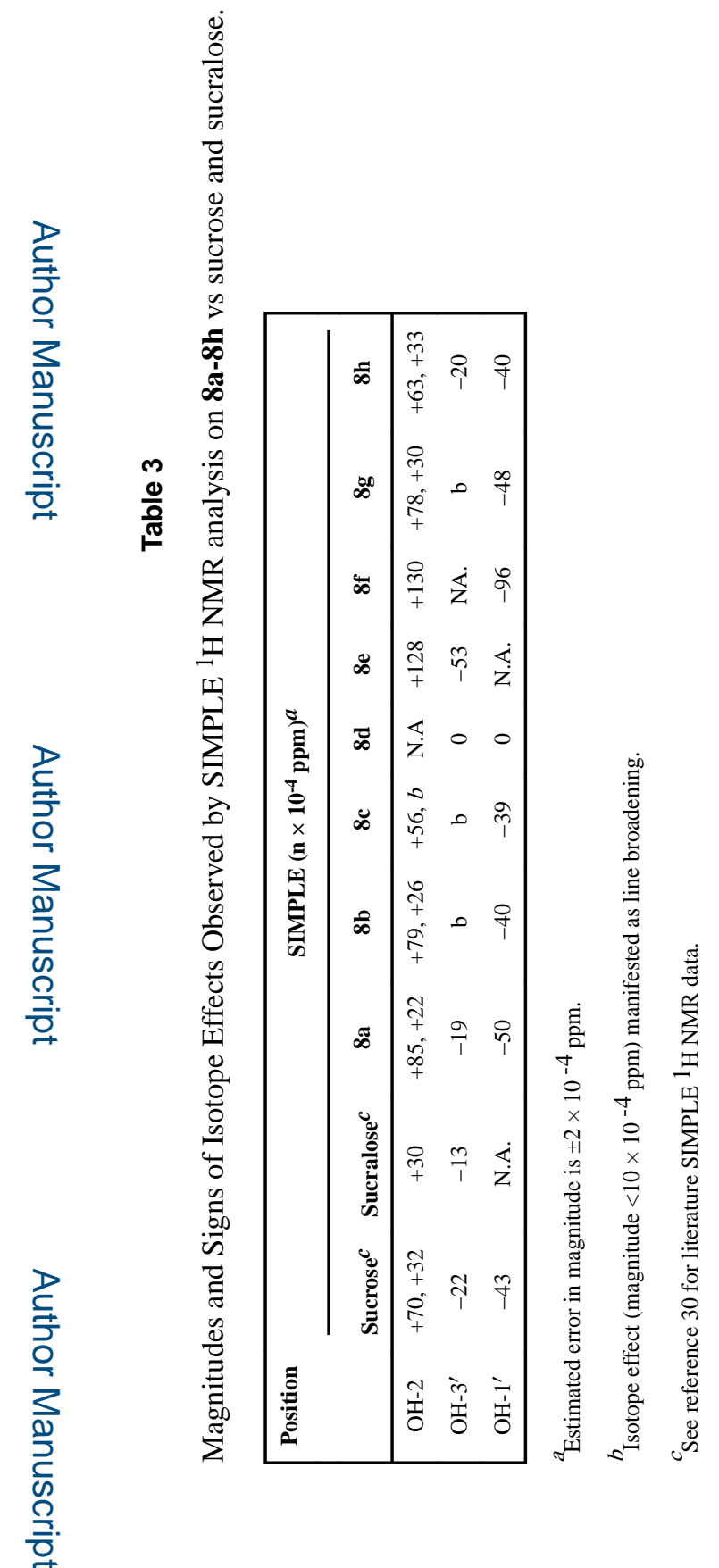

